\title{
[11]
}

\section{History and the Redefinition of Custom on Kilimanjaro}

\author{
Sally Falk Moore
}

Local customary law "systems" within present African states are referred to from time to time in legislation and in the courts. These references read as if preserved parts of previous traditions actually existed intact. In Tanzania the Primary Courts are specifically given jurisdiction over cases arising under customary law (sheria ya mila) (Maelezo 1964). Yet it is obvious that in practice the congeries of custom that do survive enjoy their continued life in profoundly altered political and economic environments and have themselves changed in a variety of ways. The "customary rules" that do remain in use are not necessarily Tylorian "survivals," anachronistic fragments of the past that are neither part of nor appropriate to a contemporary world (Tylor 1958:70). Instead, they must be seen at this moment as integral elements in an ongoing political order. In Africa the invocation of tradition can be as much a way of resisting the government as a means of cheating one's brother.

Present-day clusters of local legal "traditions" therefore require interpretation in at least two apparently contradictory dimensions-the dimension of formal continuity over time and the dimension of sequential transformation. Emphasis on the sameness of form over time has often been important both in the strategies of individuals and in the policies of governments. The very concept of "customary law" has legitimating implications. 
However, "custom" also means current local practice that may or may not be tied to the deep past. As a legal scholar of the Middle Ages named Azo (d. 1230) said a long time ago, "A custom can be called long if it was introduced within ten or twenty years, very long if it dates from thirty years, and ancient if it dates from forty years" (Plucknett 1956:308). Tradition as it was and practice as it is are not necessarily the same. Context, content, and meaning shift, even as familiar forms are repeated for new reasons.

This chapter is an attempt to communicate a sense of the practical facts and theoretical significance of a historical instance of such metamorphoses - the past one hundred years of legal change among the Chagga of Mount Kilimanjaro. ${ }^{1}$ If law in such a setting is analyzed over time, situated in the life of a particular community, then it follows that the changing circumstances of that community are part of the content of its legal system. To abstract legal ideas from the operating community in which they are "used" generates the kind of categorical and semantic analysis recently produced by Geertz (1983:167). That kind of approach may tell us about ideological forms, but such "linguistic" or "literary" analyses of the conceptual elements in a legal order do not take one very far in understanding what people actually do on the ground or why they do it at particular times and places. I agree with Geertz that it is essential to know in what terms people think about basic moral and legal issues. Yet, however elegantly such ideas may be described, presenting the "traditional" categories of legal discussion without the context of discourse offers statements without speakers, ideas without their occasions, concepts outside history.

Instead, the two case histories of land disputes below, both chosen from the 1969 period, provide time-grounded instances of the use of "customary law" on Kilimanjaro in Tanzania. These stories make it clear that certain basic ideas with their source in the culture of a century ago are still current on the mountain and that they inform practice. But there is no way to read these microhistories without also noting that a cash crop is grown on the land that is often piously talked about in terms of the buried bones of the ancestors, that interests in the same land were recently being bought and sold, that some of the players in the local drama are salaried teachers as well as landholders, while others are solely farmers, and that down the road there are courts and officials who

1For a much more detailed historical account of the transformation of "customary law" on Kilimanjaro, see Moore 1986, which had not been published at the time the paper that is the basis of this chapter was presented. 
are local agents of the central state. What is visible in the case histories is the surface of the complex intertwining of "old" and "new," of "customary law" and the coffee connection, of present relationships and old cultural forms.

That this product of history cannot be satisfactorily accounted for solely through a description of its interwoven present is evident. Anthropological fieldwork necessarily relies heavily on exploring what people understand their situation to be at the time they are observed. Yet close synchronic description, for all its irreplaceable value, necessarily limits analysis through enlarging the importance of the observed moment. Fieldwork being what it is, anthropologists are almost methodologically committed to overvalorizing what they observe and are told. That is the way the experience of others becomes part of their own. Yet where a longer historical background is known, awareness of that deeper past can change the way the observed present is analyzed. The present can be reconceived as the product of a sequence and as the moment before the future, as a scene in motion. Inquiries can be made into the conditions that have formed, transformed, and propelled these elements of which the present is constructed through given trajectories into their current combinations. Thus, after sketching the facts of the local case histories from the 1969 period below, I shall turn to the larger-scale historical background. Some conclusions about the concept of customary law itself follow.

\section{Anticipated Inheritances: Two Case Histories from the Late 1960s}

\section{The Locale}

On Kilimanjaro, in one of the Catholic districts past magnificent waterfalls bounded by steep ferny cliffs, lies the little subparish (mtaa) of $\mathbf{R}-$. It is a maze of gardens interplanted with bananas and coffee bushes and vegetables. One neatly hedged garden is immediately next to another. Between them, a living fence of dracaena marks the boundary. Looking through the plants from the paths that wind in and out of the homestead plots, one can glimpse the outlines of dwellings. There, in the middle of the plantings, lives a Chagga household, and sometimes more than one. Contiguous gardens often belong to agnatically related men, so a subparish is composed largely of localized patrilineal clusters, with some scattered individual households interspersed among them. 
This green, leafy haven with gently flowing irrigation canals looks like a rural paradise. But it is not a paradise. An acute shortage of land disturbs all relationships, and a more difficult future hangs over the present. Men with enough cash are always looking for ways to buy a little more land for themselves. They want it for their own purposes now, but later for their sons. However, most men do not have enough cash to buy land. Only those who have salaried employment or small businesses or other access to money besides coffee find it possible to buy land. Most men acquire their land from kinsmen in the normal course of allocation and inheritance and have no means of acquiring more through purchase.

The "customary law" rule is that a father should provide his eldest son with a banana grove of his own on marriage, and that the youngest son should live in his mother's (or parent's) compound for life and bring his wife there and raise his children there and eventually inherit the parental house and land. Middle sons are supposed to look after themselves and go cultivate new plots in the bush. But that last rule cannot be obeyed. On Kilimanjaro there is no bush to cultivate, so when there are middle sons there is a serious problem of providing for them. In fact, even when there are only two sons, the paternal kihamba (banana) garden often is not large enough to divide for the support of two, let alone three, households.

For as long as anyone has known anything detailed about Chagga horticulture, the Chagga have relied primarily on their permanent, well-manured, and often irrigated banana gardens high on the mountain. Annual crops of maize, beans, and millet have also been cultivated on auxiliary plots in the lower areas to enlarge the food supply. In the old days, and in some places today, those maize lands toward the foot of the mountain were not held permanently and were farmed in a form of shifting cultivation, reallocated annually by the chiefs. These annualcrop lands were soon exhausted and had to lie fallow. At that point, a new area would be designated for cultivation and divided by the chief or his deputy. As population increase has forced the Chagga to spread down-mountain, and as further irrigation and fertilizers have made some lower areas more habitable than they once were, some of these lower area shambas have come to be permanently occupied.

In families with severely inadequate amounts of land, married sons without plots of their own sometimes build dwellings in the compound of their father and seek work as occasional laborers in the gardens of others. Life is difficult and impoverished for them. Only the households of shopkeepers and salaried persons are securely well-off. For every such 
prosperous household in a localized lineage, there are many others that are poor. Many live exclusively on the products of the small plots of land they have inherited.

This is the general setting in which the following case histories were collected. Both involve allusions to "customary law" rules as used in and out of the courts. The stories of the specific fortunes and misfortunes of these particular families demonstrate clearly enough the general persistence of a nexus of rule-statements and practices that historical evidence connects with the deep cultural past of the Chagga. They also sharply attest to the modernity of these uses of the "traditional."

\section{Case 1: Bounded Lands and Limitless Hatred}

In the parish of $\mathrm{R}-$ there was a father with two sons. As they reached adulthood and married, the father divided his banana/coffee garden into two parts and gave each son half. He did not stay to live out his years in the half of the younger son, as custom dictated. He had the resources to make other arrangements for himself and went to live permanently in a shamba he had in the lower area.

The two sons were very different, and the course of their lives differed almost from the beginning. The firstborn son was a good student and eventually became a teacher. His respected, salaried job and his education made him one of the well-to-do men in the parish of $\mathrm{R}-\mathrm{He}$ married and had children, and for a long time all was well with him and his household. The younger brother did not fare as well. He never got past "standard four" in school and was functionally illiterate. He had no job to supplement the meager subsistence he and his wife scratched out of their land. Worse still, his wife bore him no children. This barrenness went on for so many years that it became plain there never would be any children from that household.

In such situations among the Chagga, suspicion inevitably develops between the wives of the brothers. The wife with children is likely to be suspected of having caused the barrenness of the wife without children. In this family there was no doubt that, in the absence of male issue in the younger brother's line, the elder brother and his line would eventually inherit all the land. Whether the wife of the elder brother had used witchcraft materials or was a witch, or whether she had simply cursed her sister-in-law, invoking the power of the Christian God, was not clear. But that she had used some such illicit means to achieve her ends was the talk of the neighborhood. 
Now it happened that the teacher was posted to a school in another place and came home to the village of $\mathrm{R}-$ only during the holidays. Gossip in the village had it that on one occasion, just before leaving, he told his wife that she should pull up the boundary plants that marked the border between their plot and that of his younger, childless brother. He was said to have told her to "make herself at home" there and to plant vegetables. She did so in an area that was roughly ten paces by five in what had been the banana garden of her husband's brother. She also planted a new boundary at the edge of the area she had cultivated. The brother whose land had been encroached on was enraged and complained to their father.

The father returned to $\mathrm{R}$ - to try to make peace between the households of his two sons. With his own hands he pulled up the dracaena that had been placed at the new boundary, and he restored the old boundary and marked it with new plantings of dracaena. This he did before witnesses. The wife of the teacher was very angry about this and took her revenge. She went to the courthouse and complained to the magistrate that her father-in-law had violated Chagga "customary law" by entering her compound in the absence of her husband, his son. There is indeed a rule of customary law that a father-in-law should not approach his daughter-in-law, or enter his married son's compound, unless the son is present. The magistrate decided that the case was one that would more suitably be heard by lineage elders than by the court. Not long afterward, the elders convened and heard the dispute. The wife of the teacher not only lost her case, but was fined one pipa and eight debe of beer for violating the dignity of her father-in-law, to whom she owed respect. He was said to have been grievously and unforgivably insulted by being taken to court in this manner and on this charge.

The wife of the teacher did not brew the beer that she was fined and never paid it. Instead, she once again pulled up the boundary plants and placed them where she had put them before, and once again began planting in the area she had staked out. Her father-in-law again assembled witnesses and pulled up the dracaena. The daughter-in-law returned to court and this time was more successful. The father-in-law was put in the lockup for three days for having broken the peace and trespassed on his daughter-in-law. When he emerged from the cell, the father-in-law prayed to God to curse the disputed land and the woman who had created such disorder.

Not too long after, the wife of the teacher fell ill and went to the hospital. She returned home, but she never recovered from her illness. 
After a time she died. After her death, the father-in-law went to the banana garden of his son the teacher and said that it was now finished, that what he wanted had happened. Then he told his son the teacher that if he took the land of his brother without paternal permission all his children would die. The teacher was obdurate and told his father he would not return the piece of land taken from his younger brother unless and until the father brought back to life the wife he had caused to die.

Neither the father nor the younger brother would speak to the teacher thereafter, and the father provided the younger brother with another place to live near him in the lower area. The teacher was left in possession of the cursed piece of land in addition to his own plot, but it was said in the neighborhood that he did not dare eat any food that had been planted in that land for fear he would die. Nor could he go to his father to ask his pardon because of a conditional curse he himself had brought forth. During his wife's illness, when the teacher accused his father of bringing sickness to his wife, he also had sworn a mighty oath that should he ever ask his father's pardon the father should quickly follow the deceased wife into the hereafter. No doubt he had hoped thereby to frighten his father and save his wife. But his efforts were to no avail, and he was left a widower who could not beg his father's pardon. All the same, it seemed clear that he and his sons would inherit the cursed banana garden after all.

\section{Case 2: The "Kidnapped" Heir}

Under "customary law," a man who wanted to alienate a piece of land and give it to a nonkinsman could do so legitimately only after obtaining the consent of his agnates. That rule was of urgent interest to a well-to-do man named Antoni of the lineage of $\mathrm{N}-$, who wanted to buy a small banana garden next to his own that was about an acre in size. Antoni had a salaried job at the mission, and his wife was a teacher, so he was a comparatively rich man. The plot he coveted was encumbered in a complex way. It had been the property of old man Salewi of the $\mathrm{K}-$ lineage, who had died a few years earlier. One of Salewi's wives had lived there with her two sons, Paul and Jacob, as they grew up.

In terms of Chagga customary law of yesteryear, her banana garden might have been expected ultimately to become the property of their youngest son, Jacob. But land shortage has produced revisions of practice. Now it is just as much a matter of practical custom for a father to divide the plot of his wife between her two sons as to leave it all to the 
younger in the traditional manner. The legal question at issue in this case history has to do with whether Paul, the elder son, had a right to a share of his mother's land. In 1969, only Jacob, the younger son, and his household lived in his mother's plot and used the proceeds from its produce. Both Paul and Jacob were entirely dependent on farming for their living. Neither had any additional source of income.

The elder son, Paul, did not live in the parish of $\mathrm{R}-$ at all. His father, Salewi, had given him a bigger piece of land in one of the lower areas, near Himo, a market center on the main road. Paul worked the land his father had given him and lived in the lower area with his wife and son. At first they occupied a rented house, but in 1969 Paul decided to build his own house in his own lower-area plot and started to do so, but to complete the house he needed more cash. At that point Paul decided he wanted to sell what he claimed was his rightful share of his mother's plot in the parish of $\mathrm{R}-$ - He was in need of money, and this seemed the only way to raise enough cash. He went to the sub-village head to tell him about his plan to sell the land to Antoni, as required by law. (The sub-village head happened to be a lineage relative of Antoni.) Paul told his own agnates about his plan and gave his kinsmen an opportunity to buy. This right to first refusal was the modernized version of the consent of agnates required by Chagga customary law. None of the lineage kinsmen came forward with an offer, so after a few weeks Paul posted the necessary formal notice in the local court announcing his intention to sell. At that time the notice had to be posted thirty days before the sale to give anyone who might have claims an opportunity to come forward. At first, no one made any objections known.

Antoni (the unrelated neighbor) went ahead and paid Paul 1,500 shillings toward the purchase price. However, in Chagga law the right to land does not pass until the full purchase price has been paid. The deal was by no means complete. This, of course, was known to several of Paul's kinsmen. They did not tangle directly with Paul, but went to his house near Himo and persuaded his sixteen-year-old son, Donasia, to come with them to R-- to claim that the land was not his father's but his own. The implication of such a claim was that Paul was trying to alienate property that did not belong to him, and hence that he had nothing to transfer. Toward making this case, Paul's kinsmen brought young Donasia to R--- and placed him in the protective care of the senior elder of their lineage, the lineage of the $\mathrm{K}-\mathrm{s}$. The senior elder is the ceremonial head of the localized lineage. His authority rests on his position as the ritual intermediary between living agnates and the lin- 
eage ancestors. To offend him carries significant risks, this-worldly and other-worldly. Paul was enraged, but there was not much Paul could do because young Donasia had been persuaded that his father was doing him out of his rightful property. The $\mathrm{K}-\mathrm{s}$ also whispered in Donasia's ear that if he ever showed his face in Paul's house again Paul would kill him. Donasia became the instrument of his relatives' intentions.

The claim of the K-_ $\mathrm{s}$ was that Salewi had left what might have been his eldest son's share of land directly to his grandson Donasia. There is in Chagga "customary law" a rule that a grandfather may skip a generation in his allocations to leave land to the firstborn son of his firstborn son if the son is already well provided for. That the firstborn son had land was clearly the case in this instance. What was not so clear was whether Salewi had in fact made such a generation-skipping allocation.

Meanwhile, Paul's younger brother Jacob was living on and using the very land that Paul and Donasia each claimed. In June 1969, Jacob took Antoni, the prospective buyer of the disputed plot, to court and alleged that Antoni had uprooted nine coffee trees in Jacob's property. The disputed plot was contiguous to Antoni's and had a common boundary with his. Jacob alleged furthermore that Antoni had thrown stones at Jacob when Jacob passed on the path in front of Antoni's compound. Antoni managed to get the case dismissed. He contended that Jacob and Paul had themselves uprooted the trees to frame him and to prevent him from completing the purchase of the land.

After winning that victory, Antoni lost the next round. The $\mathrm{K}-\mathrm{s}$ appealed to the village executive officer and managed to persuade him to stop the sale. The executive officer was taken to the garden in question and shown the place where the bones of the $\mathrm{K}$ - ancestors were buried. This was proof that this was patrimonial property and according to Chagga tradition should not be sold without the consent of all. But the village executive officer also told Donasia that if he wanted to keep the land he would have to find a way to pay back the 1,500 shillings Antoni had already invested. Donasia had no idea where he could get the money. He feared his father too much to approach him, and evidently with good reason.

Donasia's father, Paul, was known to be a very excitable and violent man. I was told that his sibling, Jacob, took the precaution of putting a spell on him to try to keep him calm through this period of altercation. It seemed very desirable to do so, as suddenly there was another bidder who offered to pay even more than Antoni for Paul's share (or Donasia's, as the case may have been). The person who came forward with the more 
tempting alternative offer was none other than the teacher in Case 1, a neighbor of all these contenders. There would be no end to the story.

\section{Interpreting the Two Case Histories}

This account of the two disputations has mentioned certain large-scale circumstances that lie behind the pressure on the land: population increase and the cash-cropping of coffee. The logical link between land shortage and bitterly disputed claims is not too difficult to find. Without land there is neither enough produced food nor enough coffee cash to buy food. Unless a landless man manages to get a wage-paying job (and those are few) or already had an income-producing business (and those are still fewer), landlessness can bring the poor perilously near to death. It can be physical death from hunger, or social death from the need to leave the community in search of a better situation elsewhere. The other form of social death is to be without offspring - at the end of the line. If you have male children, you need land for them; if you have no male children, it must mean that your agnates covet your land.

Belief in the potentially lethal repercussions that follow from oaths and curses are part of Chagga cultural cosmology. These misfortunecausing consequences of human words and occult acts are as consistent with present versions of Christianity as they are with precolonial Chagga ideas about the power of the dead over the living and the nature of "witchcraft" and "magic." The cases present word-caused homicide as a fact. Whether what is said is so or not is generally regarded as contingent, as possible. There are often differences of opinion. This is the way it comes up in conversation. Land shortage is death-dangerous in more than one sense.

Submerged in these two stories as well is the march of an unrelenting process, the process by which the better-off Chagga men try to do their poorer relatives and neighbors out of their land. In both these cases, we see that it is the salaried men (the salaried teacher in the first case, and the salaried mission-employee, Antoni, in the second) who are energetically on the road to acquiring more land. In both stories these acquisitive men or their wives are accused of offenses, and their antagonists use other legal maneuvers to try to foil their plans. The ultimate outcome of these particular struggles had not emerged at the time this material was collected. Indeed, in a sense, such struggles are unending. Nor is the outcome fully predictable in any particular instance. There are many 
possible reversals of fortune that even a relatively prosperous man may suffer. But in the long run it seems clear that the better-off, the more literate, the more able to get along in the modern sector will be able to outdo their less fortunate agnates and neighbors in the competition for resources. Even so, their accumulations will soon be subdivided among many offspring. Demography keeps wealth in check.

Thus, the case accounts only hint at economic differentiation and asymmetry of power, because these are not matters open to verbal disputation; they are incontestable circumstances. Instead, the discourse in and surrounding the cases goes to some lengths to present the normative rationales the claimants made for their arguments. That is where "customary law" enters the picture. Presumably some of the factual claims were fabricated. What is not individually constructed is the culturally embedded legal rationale. That commonality can be verified from other case histories by the dozen. (See Moore [1986] for an extended description of the content of "customary law.")

The two land case histories are classical instances of recent situations that the Chagga themselves characterize as "customary law" cases, instances involving the mila, the customs of the Wachagga. Both involve practices and ideas that refer to the past but that are closely woven into the present fabric of rural Chagga life. It goes without saying that the Chagga know as well as anyone else that there are occasions when it is convenient to invoke tradition to obtain property. For other purposes, the very same people are likely to say that times have changed and new ways of doing things are more appropriate. The choice of the "modern" perspective or the "traditional" is often clearly a matter of strategy.

But the availability and the plausibility of the particular traditional arguments is not to be explained solely by the way they figure in the strategies of individuals. To take the actor's perspective in that narrow sense ignores the larger-scale conditions that determine the limits of individual choice. The parties to such legal disputes are not fully free to constitute their own reality. To a great extent they operate constrained by general circumstances that they do not control, and they are often subject to quite specific limitations set by more powerful others. These kinds of contextual constraints and asymmetries of power are the preoccupation of much current social theory (Lukes 1986). The problem is to keep a balance between the task of uncovering determinants and the task of identifying possibilities. What Bourdieu has proposed, both with his concept of the habitus and in his books on education and on taste, and what Willis has argued even more forcefully in Learning to Labor, is that 
even what is experienced by the actors as purely strategic, innovative, or rebellious choice-making ultimately has, on the large scale, the effect of "reproducing the system" (see Bourdieu 1977, 1984; Bourdieu and Passerson 1977; Willis 1981). No one would argue that there are no continuities in categorical hierarchies and the various asymmetrical relationships they spawn, but the "reproduction" model is rigidly static as a total framework of analysis and it leaves a huge question unaddressedHow then do systems change? Neither Bourdieu's model nor Willis's interpretations fully addresses that question. How is an anthropologist working at the micro-social scale, nose-to-nose with the protagonists, to distinguish the process of change from the process of reproduction if both present themselves as change?

The solution is difficult and not always practical. Whenever possible, the local, small-scale, actor-centered materials of fieldwork must be reinserted into the long story of historical transformation. It is only because he knows what happened afterward that Sahlins can make what he does of the misadventures of Captain Cook (Sahlins 1981, 1987). Only because I know what happened before can I see Chagga "customary law" of the 1960s and 1970s as something very different from the late nineteenth-century body of practices to which "customary law" implicitly refers both for legitimation and for some of its specific cultural content. There is an impoverishment of understanding when an ethnographic situation is stripped of its deeper temporality. For the Chagga the question why certain traditional legal claims, arguments, and ideas have remained viable while others vanished is in large part answerable, but to answer it properly requires attention to history. Part of that story can be told succinctly.

\section{Reorganizing the Chagga as a Project of Governments}

For a century governments have been telling the Chagga what they may and may not do and what parts of their system of "customary law" were acceptable and enforceable by the state and what parts were not. Colonial governments, first German (1886-1916), then British (191661 ), had a variety of plans to reorganize, control, and reshape Chagga life. (The missionaries and settlers who arrived with them had their own agendas too.) Since 1961 the postcolonial government, with its program of African socialism, has undertaken new reforms under very different ideological banners, but independence from colonial rule for the nation 
has not meant independence from central government directives for Tanzania's peoples. Dictation of change from above continues.

Given such a past and such a present, developments in the local system of "customary law" over the century can be seen as taking place in what is officially regarded as a residual category. At first, "customary law" was that part of an earlier way of life with which colonial government institutions either deliberately chose not to interfere, which they could not easily alter, or which were left in existence because they fell outside the locus of administrative attention. The distinction between "customary law" and government-made law was originally a product of the colonial encounter, but that encounter did more than create two parallel legal categories, one new and one old. It determined what part of the old would be preserved-or rather, it determined that part of the old would not be preserved. The rest-the residual category that did not offend against colonial definitions of morality and that was not inconsistant with colonial law and policy-was permitted to continue. Over time, substantial changes appeared in the content of that "customary law" sector. That is not surprising. The most important formal change in the place of traditional Chagga "customary law" which also affected its content is the fact that from the beginning of the colonial period to the present it has been harnessed to political and economic structures that are entirely different from those existing in the late nineteenth century. ${ }^{2}$

Direct state interventions in Chagga affairs, and their legal consequences, could be illustrated in a number of different ways, but none is more telling than the history of Chagga formal organization. A knowledge of the drastic reorganizations worked by governments puts in proportion the other half of the story: the fact that the localized patrilineages of precolonial times sought to preserve a degree of autonomy and succeeded in remaining significant entities in the allocation of property.

Much of what was transformed on Kilimanjaro in this century was changed through the agency of three major organizations of European provenance introduced on Kilimanjaro during the colonial period. All three are still there, and still very important, though they are now present in mutated forms. One was the Christian church, in Lutheran and Catholic versions, together with their mission schools and hospitals. The second was the national, provincial, and district administrative

\footnotetext{
${ }^{2}$ And the late nineteenth century undoubtedly was very different from the early nineteenth century. See Stahl 1964 and Iliffe 1979.
} 
structure now run through the national party (first called TANU, now CCM). The third was the coffee cooperative through which all Chagga have sold their coffee since the 1920s. In one sense, because the indigenous system of localized patrilineages has persisted, these other organizations of European origin might appear to be merely additions to, rather than replacements of, the most basic indigenous arrangements. But the powerful presence of these ubiquitous organizations worked deep alterations on every imaginable aspect of Chagga life and thought. They were inside the rural Chagga neighborhoods, not outside. Virtually every Chagga household belonged to all the organizations and was directly affected. As universal membership organizations to which virtually every household "belonged," they transformed economy, politics, religion, and knowledge.

The nineteenth-century Chagga chiefdom, as it had been, has utterly vanished. The precolonial chiefdom had a closed constitutional framework that permitted only certain kinds of groups to be formed. Chagga chiefdoms were a variant on a familiar East African pattern, with entities defined by kinship (exogamous segmented patrilineages and their member households, chiefship descending in one of the lineages), political entities defined by community, geography, and authority (subdistricts, districts, and chiefdoms), and crosscutting structures of mobilization defined by age (formal male age-sets and age-grades, and a less frequently activated and more generalized classification of women by age category). Military service and corvée labor were exacted through the male age-sets. In addition, there were irrigation canal users groups (groups of men whose household gardens shared the same man-made watercourse). The "canal users group" was sometimes coincident with the subparish, sometimes not. New groups were constantly being formed, but they were constituted within the framework outlined. There were new groups, but not new kinds of groups.

This system of chiefdoms, districts and subdistricts, lineages, agegrades, and water-sharing groups constituted the total formal corporate organizational structure of the Kilimanjaro area in the late nineteenth century (see Gutmann 1926; Moore 1986; Stahl 1964). People could be mobilized for collective action through each of these entities. Each kind of group had not only an important productive role in the economy, but also substantial powers of control over its members. For males, they were what I have called "universal membership organizations" (Moore 1986:310-317) —all men belonged to all of them. The achievement of self-acquired social position took place largely within these milieus, as 
did transmission of property and position from one generation to the next. Each level and type of organization had its own internal means of enforcing its control over members and of hearing and closing episodes of dispute that arose among them.

There was, in practice, a degree of fluidity in the alignments and numbers of the collectivities that made up a chiefdom, and a degree of flexibility in the choice of leadership. Chiefs routinely stepped down in middle life in favor of their sons. The succession could be accelerated or decelerated as the political situation required. Chiefs could also be deposed and replaced. Households could move from one chiefdom to another. The chronic raiding and fighting both among the Kilimanjaro chiefdoms and with "outsider" chiefdoms, which characterized late nineteenth-century life, provided many opportunities to rearrange Chagga political affairs (and even to do away with incumbents in office) or forcibly to persuade chiefdoms to change their alliances or to become tribute-payers and clients of those who threatened them most. The control over regional and long-distance trade must have been a major factor in all this turmoil. The monopoly of chiefs over the most important items in the trade, especially over ivory, captured cattle, and other trade goods, gave chiefs a strong hold over the key people in the chiefdom. The chief, through redistribution, could offer incentives as well as deploy threats in relation to subordinates.

Once the colonial period began, all the balances in this political arena changed, even though some of the basic constitutive elements of its form continued in being. Warfare ended, the military aspects of the age-grade system were abolished, and the long-distance trade completely changed its character. Chiefs lost their acquisitive and redistributive monopolies, and Europeans took over the marketing of significant commodities. What had been independent chiefdoms became subordinate administrative units in a colonial state. The cash-cropping of coffee was introduced, and eventually coffee was planted by virtually every household in its own land. The Chagga continued to grow subsistence crops as well. Most families were converted to Christianity. Schools and shops sprang up. The population doubled and doubled again, going from 100,000 in 1900 to almost 500,000 in 1978.

All the while, in form, many of the major local organizational units of precolonial times were maintained. Chiefdoms, districts, lineages, and the water-sharing groups persisted. Some became larger, some smaller, some new ones were founded, some old ones abolished. But each type of entity continued, many just where they had been before. In 1961 chief- 
ship was abolished once and for all, and a new formal division of administrative units was brought into being. But they were for the most part composed of the same old basic subdistricts and other low-level organizational entities that existed before. These continue in metamorphosed versions to this day. However, though locally conceived in terms of their continuity, the content and milieu of these organizational frameworks has continuously shifted and changed.

From the 1890s to 1961, each chief became more and more an agent of the administrative apparatus of the colonial state, collecting taxes, enforcing regulations, and presiding over a court-the jurisdiction of which was carefully limited by the government. With warfare gone and the long-distance trade in other hands, political rivalries shifted their focus. The colonial administrations, both German and British, gradually reduced the number of chiefdoms by half. Thus some chiefdoms became subordinate to others and lost their chiefly office. The manipulation of choice in this matter was not without input from the Chagga chiefs themselves. Politics became focused on position in relation to the colonial authorities.

Continuing a process of consolidation begun earlier, the British completely reorganized the structure of local government, creating new levels of administration and a type of centralization that had no foundation in the Chagga past. They united all the Chagga chiefdoms. By 1929, all the chiefs were grouped together in a single council, and that council not only became a legislative body through which many colonial ordinances were promulgated, but also was constituted as a court of appeal. The power of the chiefs in their local chiefdoms was gradually diminished. In place of the earlier almost complete judicial separateness of each chiefdom, the chiefdom courts over which they presided had become the lowest judicial bodies in a local hierarchy. By the late 1920s the chiefs had been put on salaries paid out of tax funds, and their tributedemanding powers were curtailed. After independence, in 1961, though chiefship was abolished, most of the local courts the chiefs or their delegates had presided over for most of the century were continued in the same sites. Their place in the national hierarchy of courts was changed (Moore 1986:159-160). They were renamed Primary Courts and presided over by an appointed "magistrate." It was to such a court that our protagonists in the land cases went with their various tales of woe.

A process of economic reorganization parallel to the administrative consolidations of the chiefdoms and to the creation of the judicial hier- 
archy was undertaken. In the 1920s, at the instigation of a colonial officer in the district, the coffee cooperative was begun in order to centralize coffee sales and regulate production. The parallel between administrative centralization and the concentration of economic control is striking, as was the use of the law to effectuate this coordinated development. The cooperative came to be extremely successful, but that was a matter neither of accident nor of local popularity. A law was passed that in effect made it illegal for the Chagga to sell their coffee to anyone other than the cooperative. There was to be no competition. Consequently, regulation and taxation of the coffee crop became much easier for the administration. Thus, supralocal centralized organizations to oversee the political and economic goings-on in the chiefdoms were in place more than fifty years ago.

Meanwhile, on the ground the localized patrilineages continued to control most transfers of land between kin, but it was not for want of trying to bring all land matters under central administrative control that the colonial government failed to do so. In 1930, to this end, the government proposed that a system of land registration would be beneficial. This was met with strong demonstrations of protest from the Chagga. Any intimation that the existing system of land tenure might be interfered with in any way was unacceptable. Although in 1930 land was beginning to be bought and sold, the colonial government could not take the political risks involved in tampering with the "traditional" system of land tenure. The reaction had been too strong. The Chagga were extremely wary on this point. It remains to be seen whether now, more than fifty years later, the independent government will fare any better if it undertakes fundamental interventions.

This cursory review of governmental, economic, and judicial reorganizations on Kilimanjaro, while lamentably limited as historical narrative, illustrates certain unstated but implicit definitional boundaries of the residual category "customary law." As perpetuated by colonial and postcolonial governments, the category obviously excluded most of those aspects of traditional law that had to do with political organization. Even where political offices were nominally continued, their attributes were carefully redefined by administrative fiat and legislation. Virtually all supralocal organization, political and economic, has been firmly under the control of regional and central authorities from the start of the colonial period to the present. By these means, political challenges to the state have been contained and certain local affairs have been directed from above. "Customary law," if understood as allowing local 
people to do their own cultural "thing," should also be understood to have been a carefully restricted fragment of "tradition."

As it turned out, the control of political affairs and of the coffee crop did not preclude leaving the allocation of individual rights in local land to the patrilineages. Thus the principal productive resource, the land, has remained in the domain of "customary law" to this day. As might be expected, however, the new product, the coffee, is governed by a new set of "customs."

\section{Changes in the Content of Customary Law}

Many stated norms of kinship tradition remain as they were, however the milieu has changed. With new kinds of property and a new environment, many new norms have also been generated to keep company with the old ones. Some examples of these changes follow.

\section{Land Rights Conveyed from Fathers to Sons}

The two case histories at the beginning of this chapter show plainly that, these days, the "customary law" rule that the youngest son should inherit his father's homestead and garden is often honored in the breach. In conditions of land shortage, other considerations prevail. The Chagga make the moral assumption that some land should be available to any decent married man. Where there is no one else to provide it, since there is no virgin land to pioneer, a father should try to provide some of his own land for each of his sons. If a father has several plots in scattered parts of the mountain, he may divide his holdings, sending one son away from the lineage cluster and keeping the other, or he may move himself. As indicated earlier, where the only solution available is to divide his own garden, a father may well do that, or if the father does not divide the land before his death, his kinfolk may do so after he dies. But a father may choose not to divide his land, and a son may find himself obliged to enter the migrant labor force or volunteer to be a pioneer in one of the new cooperative villages.

Whatever the pragmatic outcome in any particular instance, the "customary law" rules continue to be restated, and from time to time they actually do guide behavior. What are we to make of this? Is the "customary law" of succession and inheritance in existence or not? And is such a rule a law if, though a son may make claims on his father and may 
legitimize his claims by invoking customary rules, the son still cannot force his father to provide for him in the customary way? Could he ever do so? Today if the son makes his claims before a group of lineage elders, he may or may not succeed in getting them to decide in his favor. And even if they do side with him, the father may or may not heed their directives. Fathers had the right to disinherit sons in the customary system, and there is every evidence that they still claim this right and sometimes exercise it. When land questions get to the courts, the outcome may depend not on who is right but on who controls the key witnesses.

It is probably fruitless to speculate on whether the practice of dividing land represents a dynamic direction that might eventually end in an explicit change in the customary rules. It is clear that "customary law" statements can coexist as cultural artifacts contemporaneously with contradictory practices and contradictory norms. The Chagga emphasis on the existence of customs that only they are competent to administer is part of their use of tradition in their present political situation. Under these circumstances, there may be value for them in refraining from explicitly acknowledging change in the system to the extent of describing new practices as new rules. The definition of "customary law" that was a product of the colonial period has had substantial effects on the Chagga conception of the scope and nature of custom, and the scope and nature of their domains of autonomy.

Recently announced plans for projected changes in rural land law will, if implemented literally, generate profound new disruptions. Yet the plans may be adapted to local conditions. The government notes in its announcement of the new village plan that local custom should be respected as much as possible (Agriculture Policy 1983). Chagga peasants in the rural areas may know nothing of the plans as announced, but they have almost a century of experience in using "customary law" arguments to minimize official intervention in the sphere of their control. They are likely to continue.

\section{Coffee Rights and Cash Rights:}

\section{The Relative Position of Women and Men}

The general adoption of coffee as a cash crop on Kilimanjaro generated many rules and practices concerning the new kinds of property. These are now explained as analogies to customary rules or extensions of them to new items. So, for example, coffee bushes, being attached to the land 
and grown by the Chagga in their individually held banana gardens, have always been considered the property of the male household head, just as the bananas had been and still are. Most of the annual vegetable crops grown in the same gardens by the women of the household were regarded traditionally as female property and remain so today. Women also have rights in the crops of the shamba lands they cultivate on the plain.

It is the duty of the woman of the house to feed the family, so she cannot sell very much of her crop in the women's markets that dot the map of Kilimanjaro, but she may sell some of it. Sometimes she sells bananas, but does so legitimately only after obtaining her husband's permission because the bananas, like the cultivated land, belong to him. A widow may acquire the temporary use of the banana rights until she dies, provided she continues to reside in the plot she occupied during her husband's lifetime. The coffee rights are usually given to a male relative of her deceased husband. These he holds as a sort of trustee and guardian of the widow and her children. He should spend the monies for their benefit to the extent that the husband would have done, but these successor-guardians often keep most of the proceeds themselves. If the widow has an adult married son residing in her compound, he often has this role. When the widow dies, all rights in the land, the bananas, and the coffee revert to the male line.

The amount of cash a woman can obtain from her market sales is minute, compared with the cash a man is paid for the coffee he sells to the cooperative for processing and sale. The labor of women-indeed of men, women, and children-is mobilized in season to pick the coffee and to do preliminary processing. However, the women have no right to any share of that income. It is considered a male obligation to provide a wife and children with clothing, but that duty does not mean he has any obligation to supply her with cash as such. He may give her some cash specifically to buy a piece of cloth or a piece of meat, but he does not give her cash to spend as she likes. Thus, the rule that the coffee bushes and the coffee cash belong to men has meant that women have had much more limited access to the cash economy than their husbands have had.

A seemingly contradictory rule is that the coffee rights can be separated from the rights to bananas and land. Should the male landholder choose, he can allocate land and banana rights and keep the coffee rights. Many men do this. Thus a father who has only one plot of land may have his youngest son and the son's family residing with him in his compound. The father may be quite willing to give the son a corner of the compound 
in which to build his house, and he may designate a small area in which the son's wife may plant her crops. He may even give his son the full rights to the bananas in some part of the garden. Yet the father can retain the coffee rights to bushes growing on the same land for himself. If the son dares pick the coffee in these circumstances, he is guilty of a theft.

The legal idea of divisible and concurrent interests in the same property existed among the Chagga long before there was coffee on the mountain. Such interests existed with regard to land, crops, and cattle. The complex of rights in coffee and cash may be built on these old ideas, but the change in the economy has been so fundamental that these traditional analogies mask real innovations: the changed basis of the relative economic position of men and women, and the changed basis of the economic differentiation between households.

\section{The Buying and Selling of Land}

Rights in land on Kilimanjaro probably began to be available for cash around 1930. This inference is based on the fact that in 1927 the chiefs expressed strong disapproval and petitioned the governor to forbid the buying and selling of land (Griffiths 1930:60,88). Before that, "traditionally," land is said to have been transferred for a conventionalized payment of a cow and a goat. Land-plot histories suggest that many "traditional" transfers took place long before cash payment was a common possibility. The time at which cash became an issue was also the time at which a serious land shortage was beginning to be felt in some localities.

One suspects that the reason the chiefs opposed sales for cash is that it threatened to reduce their prerogatives. In the customary system, all unused land in theory reverted to chiefly control. There was no land shortage in the nineteenth century. Political control over people and their labor was undoubtedly more important than control over land. Land had no value without labor to work it. The land was there for the asking. In the British colonial period, as before, the native authorities, the chiefs, and their appointees, and the district heads controlled the allocation of undeveloped land, or lands that had been "abandoned." (The latter differed from the land of people who were temporarily absent, who retained the right to reclaim previously held land when they returned.) In this period, the chiefs and their subordinates received substantial "gifts of thanks" for assigning these empty plots to others; they also often gave them to their own relatives. During the colonial 
period, chiefly consent came to be required for all land transfers. This was an expansion of administrative power. The chiefs disapproved of the buying and selling of land because they did not want to give up their reversionary claims or their controls.

The chiefs did not succeed in their plan. The buying and selling of land was not forbidden, and if anything it was encouraged. Ultimately even the buying and selling of land worked in favor of the chiefs. Because they were relatively rich men they were able to afford to buy land, which most Chagga could not do. This meant that they accumulated more lands than most others and enjoyed a continuing enhanced income from their scattered plots.

There was another category of people who had enough cash to buy land - the salaried men, and those with small businesses-a category that has grown enormously since 1950 . Such men stood ready to buy land from anyone who was in debt or who because he had too small a plot to make a living was ready to leave and settle elsewhere. This does not mean that such buyers have become great landholders. On the contrary, the rise in population has been such that allocations to their many sons and grandsons has redivided the land again and again.

The purchase and sale of land has been conceived locally as an analogue of the former transfer in exchange for a cow and a goat. Indeed, when Chagga speak of past times when such transfers did take place, they often refer to them as sales, laughing at the "low price." Today, as a matter of law, the state holds all title to land in Tanzania, and rural people hold only the usufruct. A variety of national party guidelines about egalitarianism make multiple plot-holding more difficult than it used to be. Present party policy is that land should go to the tiller, but the buying and selling of the right to possession, and the right to beneficial use, continues on Kilimanjaro. Furthermore, the ingenious Chagga find many ways to place surrogates who are clients, or other dependent people, in their auxiliary plots so that the appearance of things will conform to party policies. Besides, the government policy that land belongs to those who work it says nothing about what happens when the tiller dies. On Kilimanjaro, "customary law" still reigns in such matters. Inheritance is a question of kinship. The rules, as I have shown, are subject to a great deal of situational amendment and negotiation, and probably always have been. Manipulation of this kind makes adjustments in conventional rules that are consonant with changing conditions. In name and in a certain sense in practice, much land law is still conceived of as "customary." But land law as it was no longer exists. 


\section{Conclusions}

The two case histories from 1968 and the highly condensed description of a century in the life of the Chagga show that what is now considered "customary law" on Kilimanjaro has undergone many metamorphoses. Radical changes in local and larger-scale asymmetries of power and in the economic milieu have made that inevitable. The apparent continuities of customary law have changed in semantic content. The relationships and resources to which "customary law" refers are not as they were. Rights in land in 1880 and rights in land in 1980, however similarly stated normatively, are not rights in the same kind of entity, nor are the claimants in the same situations.

The answer to the question of what the category "customary law" means in these circumstances depends on who is using the concept and when it is being used. The courts have their own way of dealing with the issue. Both in the colonial period and now, local courts were and are specifically granted jurisdiction over questions of customary law. Because "customary law" is a residual category, and because it may be different in each locality, there is no specific legislation on the point of substantive content. On Kilimanjaro, "customary law" rules are to be determined case by case in the Primary Courts (as they were in the predecessor chiefly courts during the British colonial period). Two senior local laymen, the assessors, sit with each magistrate and are to be consulted on all points of customary law. The venerable assessors are assumed to have special knowledge of local norms and practices by reason of their standing in the community.

Within this law-finding structure, at least three possible meanings are conflated. One is that custom is a set of traditional rules handed down from generation to generation. A second is that custom is a matter of present general practice. A third is a more formal judicial meaningthat custom is the residual category of local norms claiming tradition as legitimation that pertain to matters on which there has been no legislation or binding judicial rulings by the central state, yet which the state is willing to acknowledge and enforce. The actual content of such rules and practices are different from one place to another and change from one period to another.

The very idea of "customary law" implies that there is a different kind of law with which it can be contrasted; so the concept itself is the ongoing product of encounters between subordinate local political entities and dominant overarching ones. Those encounters and the legal distinction 
between law and custom have a long history in the West. In Tanzania the colonial state (and now the postcolonial state) has had reason to allow certain kinds of limited local autonomy to be perpetuated. What is left of locally specific legal custom is the result of that political decision. A variety of governments and several generations of rural people have, for very different reasons, collaborated to encode the division between the central state and its subordinate peoples in this legal duality. All anthropological studies of African law must be read in this light, and not simply as accounts of traditional thought.

Today, "customary law" on Kilimanjaro is as much a creature of the present state and the present economy as it is a link with a past cultural heritage. The theoretical implication is plain: the unit of analysis in the study of such interdigitations must encompass both local and supralocal entities, and it must do so within a historically conceived framework. Contextualization has always been the principal method of social anthropology. But there is disagreement about the nature of the context. I argue that the analytic context is not only a legal cultural system in the Geertzian (1983) sense. The shifting political and economic milieus in which the cultural elements are used are an integral part of the anthropo-logic of such cultural forms.

\section{REFERENCES}

The Agricultural Policy of Tanzania. 1983. Dar es Salaam. March 31.

Bourdieu, Pierre. 1977. Outline of a Theory of Practice. Cambridge, Eng. Mass.

Bourdieu, Pierre, and Jean Claude Passerson. 1977. Reproduction. Beverly Hills, Calif.

Geertz, Clifford. 1983. Local Knowledge. New York.

Griffiths, A. W. M. 1930. "Land Tenure Report, Moshi District." Copy in the Manuscript Collections of Africana, Rhodes House Library, Oxford, MSS. Afr. s. 1001.

Gutmann, Bruno. 1926. Das Recht der Dschagga. English translation by A. M. Nagler, "Human Relations Area Files" (New Haven, Conn.).

Iliffe, John. 1979. A Modern History of Tanganyika. Cambridge, Eng.

Lukes, Steven, ed. 1986. Power. New York.

Maelezo ya Mahakama za Mwanzo. 1964. Dar es Salaam.

Moore, Sally F. 1986. Social Facts and Fabrications: “Customary Law" on Kilimanjaro, 1880-1980. Cambridge, Eng.

Plucknett, Theodore F. T. 1956. A Concise History of the Common Law. Boston. 
Sahlins, Marshall. 1981. Historical Metaphors and Mythical Realities. Ann Arbor, Mich. 1987. Islands of History. Chicago.

Stahl, Kathleen M. 1964. The History of the Chagga People of Kilimanjaro. The Hague.

Tylor, Sir Edward B. 1958. The Origins of Culture, Part I: Primitive Culture. New York.

Willis, Paul. 1981. Learning to Labour: How Working Class Kids Get Working Class Jobs. New York. First published 1977. 